\title{
Mechanical and Tribological Performance of Self-Cured Poly Methyl Methacrylate Reinforced by Alumina Nanowires and Zirconia Nanoparticles for Denture Applications
}

\author{
AHMED EL-SAYED MOHAMED HASSAN ${ }^{1 *}$, MOHAMED NAGUIB EL-SHEIKH ${ }^{1}$, \\ WAHEED YOSRY ALI ${ }^{2}$, MOHAMED NAFEA METWALLY ROHIM ${ }^{1}$ \\ ${ }^{1}$ Production Technology Dept., Faculty of Technology and Education, Beni-Suef University, Beni-Suef, Egypt \\ ${ }^{2}$ Production Engineering and Mechanical Design Dept., Faculty of Engineering, Minia University, El-Minia, Egypt
}

\begin{abstract}
Polymethyl methacrylate (PMMA) is one of the common widely accepted biomaterials in prosthetic dentistry due to its acceptable advantages, since 1937. In the present work, PMMA reinforced with $\mathrm{Al}_{2} \mathrm{O}_{3}$ nanowires $\left(\mathrm{Al}_{2} \mathrm{O}_{3} \mathrm{NWs}\right)$ and $\mathrm{ZrO}_{2}$ nanoparticles $\left(\mathrm{ZrO}_{2} \mathrm{NPS}\right)$ were fabricated by a self-curing method. Mechanical and tribological tests were conducted to study the effect of nanofillers on the mechanical and tribological performance of PMMA nanocomposites. Compression and microhardness tests, as mechanical tests, were accomplished to estimate the elastic modulus and microhardness number of the present nanocomposites. Also, tribological properties of unfilled PMMA and its nanocomposites were realized by pin-on-disk tester under dry sliding conditions. Wear test was conducted at room temperature under applied loads of 10,20,30,40, and $50 \mathrm{~N}$ at a constant sliding speed and distance of $1.256 \mathrm{~m} / \mathrm{s}$ and $226 \mathrm{~m}$, respectively to study wear rate and coefficient of friction (COF) of the nanocomposites. Experimental results revealed that the elastic modulus, microhardness, wear rate, and $\mathrm{COF}$ were enhanced with increasing nanofiller content up to 0.5 and $0.7 \mathrm{wt}$. \% of $\mathrm{Al}_{2} \mathrm{O}_{3} \mathrm{NWs}_{\text {and }} \mathrm{ZrO}_{2}$ $N P s$, respectively. Also, wear rate increased with increasing applied loads up to $50 \mathrm{~N}$, while COF decreased with increasing applied loads up to $40 \mathrm{~N}$. Finally, specimens' worn surfaces were examined and imaged using scanning electron microscope (SEM).
\end{abstract}

Keywords: $P M M A$, self-curing, tribological performance, $\mathrm{Al}_{2} \mathrm{O}_{3}$ nanowires, $\mathrm{ZrO}_{2}$ nanoparticles

\section{Introduction}

Polymeric nanocomposites (PNCs) have been widely applied in numerous engineering and medical fields such as coatings, automobiles, and aerospace due to their appropriate and good thermal, mechanical, electrical, physical, and optical properties [1,2].

PMMA resin is the most acrylic material widely used for denture applications because it possesses a combination of suitable characteristics including inexpensive fabrication, light weight, ease of laboratory manipulation, and stability in the oral environment [3, 4]. Moreover, it is an important thermoplastic material having many applications in several fields due to its unique mechanical, electrical, optical, and thermal properties [5]. Those applications are at diverse fields like polymer electrolytes, organic sensors, biomedical, solar cells, organic electronic devices nanotechnology, nonvolatile memory, and molecular separators [6]. Another important advantage of PMMA to be used in denture applications is that its toxicity is low, while methyl methacrylate can be irritating to mucous membranes, skin, and eyes of human. Alamgir et al. [7] fabricated $\mathrm{PMMA} / \mathrm{TiO}_{2}$ nanocomposites as denature bases, where they found that these nanocomposites have high mechanical and biological properties to be used at dental applications.

Although PMMA resin has better mechanical and physical properties than other polymer materials, it has poor physical and mechanical performance when used alone, where it is easily broken [8-10]. However, it suffers from several drawbacks that need to be addressed such as poor mechanical performance that including low impact resistance, poor surface properties, low hardness, and fatigue failure $[11,12]$. Structural modifications to the composites, such as the addition of nanofillers, could

*email: a_sayed_hassan@yahoo.com 
improve mechanical properties of the PMMA acrylic. Hence, PMMA resin requires improvement in order to achieve a greater strengthening attribute [13].

Recently, nanotechnology has been employed in dental applications in which many studies have been conducted to discover the predictable benefits and applications [14]. Moreover, enhancement of PMMA has been done by means of grafting with different nano-fillers [15].

Numerous studies have been focused on enhancing of PMMA performance using different curing methods and/or incorporating nanofillers in its composition [16, 17]. Because of the nanofillers characteristics that lie at the nanometer scale, a strong interfacial interaction could be achieved between them and the matrix material, if only the nanofillers were distributed homogenously into the matrix material $[18,19]$.

Recently, there has been an increasing attention toward incorporating ceramic nanofillers into denture-base acrylic to act as a strengthening material. For example, $\mathrm{ZrO}_{2} \mathrm{NPs}$ received attention due to their superior biocompatibility as well as their white color, which makes them less likely to alter the esthetics in comparison to other nanometal oxides [20,21]. The selection of $\mathrm{ZrO}_{2} \mathrm{NPs}$ as a nanofiller in this study was based upon their ability to improve the mechanical characteristics of acrylic resins [22, 23]. There are some factors should be studied that affect the physical and mechanical properties of the $\mathrm{PMMA} / \mathrm{ZrO}_{2}$ NPs composites, including shape, size, concentration, homogenous distribution, and composition of the matrix [24].

Previous studies focused on effect of $\mathrm{ZrO}_{2}$ NPs on the mechanical performance of PMMA denture base acrylic material and showed that $\mathrm{ZrO}_{2}$ NPs have the ability to increase the impact and flexural strength of the acrylic denture base [25]. Impact and flexural strength values were increased up to $5 \mathrm{wt}$. \% of $\mathrm{ZrO}_{2} \mathrm{NPs}$. After that their values were decreased due to nanoparticles agglomeration and cluster formations that weakened the material [22]. Also, a significant increase in impact strength, hardness, and fracture toughness of PMMA reinforced with $\mathrm{ZrO}_{2}$ NPs was observed by Franklin et al. [26] and Ellakwa et al. [27], while a reduction in impact strength as well as surface hardness was observed upon the incorporation of 10 and $20 \mathrm{wt} . \% \mathrm{ZrO}_{2}$, as discussed by Asopa et al. [28]. Moreover, Kul et al. [29] showed that a significant enhancement of PMMA thermal conductivity was observed after addition of $\mathrm{ZrO}_{2} \mathrm{NPs}$.

Amongst commonly ceramic material into denture-base acrylic is $\mathrm{Al}_{2} \mathrm{O}_{3}$ NPs because it possesses excellent abrasion resistance, impact resistance, superior hardness, low cost, and high stability and resistance to oxidation and corrosion at high temperature. Therefore, it can be used in very wide range of industries including aerospace industry, medical applications in dental, adsorbents, microelectronics, catalysts, coatings for decorative effects and in the cosmetic or automotive industry and other high technological fields [30- 34]. $\mathrm{Al}_{2} \mathrm{O}_{3} \mathrm{NPs}$ have been attracting attention and have been historically more accepted as biomaterials for dental and medical applications [35]. Effect of $\mathrm{Al}_{2} \mathrm{O}_{3}$ NPs addition at three different concentrations of 1,2 , and $3 \mathrm{wt} \%$ on the mechanical and physical characteristics of PMMA was investigated by Jasim et al [36]. The results proved that the transverse strength of PMMA increased with increasing $\mathrm{Al}_{2} \mathrm{O}_{3} \mathrm{NPs}$ up to $2 \mathrm{wt}$.\%. Moreover, addition of $\mathrm{Al}_{2} \mathrm{O}_{3}$ NPs to acrylic resin to be used as base dentures led to improving the thermal conductivity and providing the patient with comfortable and satisfactory feelings [37, 38]. Several studies emphasized on the effect of $\mathrm{Al}_{2} \mathrm{O}_{3}$ NPs on the mechanical properties of PMMA denture base acrylic material. Incorporation of $\mathrm{Al}_{2} \mathrm{O}_{3}$ NPs into PMMA acrylic resin that are applied in denture base leads to great enhancement in the impact, tensile, compressive, flexural strengths, and surface hardness [25, 27, 38, 39].

Based on the previous literature, $\mathrm{ZrO}_{2} \mathrm{NPs}$ and $\mathrm{Al}_{2} \mathrm{O}_{3}$ NPs had significant improving effect on the mechanical properties of PMMA, however there were little data available related to their effect on the wear resistance and COF of PMMA acrylic base denture, so further investigations were needed. Moreover, there are no studies have yet been conducted to incorporate of $\mathrm{Al}_{2} \mathrm{O}_{3} \mathrm{NWs}$ into PMMA acrylic resin for denture base applications. Therefore, this study was conducted to evaluate the elastic modulus, surface hardness, wear rate, and COF of PMMA/ $\mathrm{ZrO}_{2}$ NPs and PMMA/Al ${ }_{2} \mathrm{O}_{3}$ NWs composites at different concentrations of nanofillers. 


\section{Materials and methods}

\subsection{Materials}

Matrix materials used in the present work are PMMA as powder and MMA monomer as a liquid hardener, that were supplied from Acrostone Dental \& Medical Supplies Company, Cairo, Egypt. While, the nanofiller materials were $\mathrm{ZrO}_{2} \mathrm{NPs}$ and $\mathrm{Al}_{2} \mathrm{O}_{3} \mathrm{NWs}$. $\mathrm{ZrO}_{2} \mathrm{NPs}(22-24 \mathrm{~nm}$ ) were supplied from Nano Tech., El Giza, Egypt. Whereas $\mathrm{Al}_{2} \mathrm{O}_{3} \mathrm{NWs}$, at dimensions of (Dia. 2-6 nm $\times$ L 200-400 nm), were obtained from Sigma Aldrich, USA.

\subsection{Nanocomposites preparation}

$\mathrm{PMMA} / \mathrm{Al}_{2} \mathrm{O}_{3} \mathrm{NWs}$ and PMMA/ZrO 2 NPs nanocomposites were prepared by self-curing method. Specimens were fabricated at constant nanofiller loading of $0,0.1,0.2,0.3,0.4,0.5,0.6,0.7,0.8,0.9$, and 1 wt. \%. This technique was accomplished by adding nanofiller of $\mathrm{ZrO}_{2} \mathrm{NPs}$ or $\mathrm{Al}_{2} \mathrm{O}_{3} \mathrm{NWs}$ to the PMMA powder in a glass beaker and mixed for $20 \mathrm{~min}$ to obtain homogeneous mixture. Then, hardener liquid (MMA monomer) was added to the powder mixture and mixed at ratio of 1:2.5 [9]. After that, the nanocomposites were molded in a cylindrical tube for $2 \mathrm{~h}$ at room temperature $\left(35 \pm 2^{\circ} \mathrm{C}\right)$ to obtain the specimen final shape. Finally, the specimens of $8 \mathrm{~mm}$ diameter and $30 \mathrm{~mm}$ length were cut into suitable sizes for further tests.

\subsection{Characterization methods}

Elastic modulus of unfilled PMMA and its nanocomposites was calculated from stress - strain curves obtained after compression test. Compression test was conducted at room temperature using SHIMADZU universal testing machine (UH series) that its cross-head speed was $5 \mathrm{~mm} / \mathrm{min}$. Standard dimensions of the tested specimens were $8 \mathrm{~mm}$ in diameter and $16 \mathrm{~mm}$ in height according to ASTM D 695.

Vickers microhardness test was conducted according to ASTM E384-99 under $50 \mathrm{~g}$ testing load for 10 seconds to estimate Vickers microhardness number of the present nanocomposites. Microhardness number was determined by dividing the applied load by square mean diagonal length of indentation. For results reliability, the test was carried out at least five times of each specimen, and average values were reported.

Wear tests were done under dry sliding conditions in accordance with the standards of ASTM G 99. A pin-on-disk test rig was used to test all of specimens that have dimensions of $30 \mathrm{~mm}$ in length and 8 $\mathrm{mm}$ in diameter as shown in Figure 1. Carbon steel disc was used as a sliding counterface, which has $185 \mathrm{~mm}$ diameter, $8 \mathrm{~mm}$ thickness, surface hardness of 58-62 HV, and surface roughness $\left(\mathrm{R}_{\mathrm{a}}\right)$ of 1.41 $\mu \mathrm{m}$. Wear test parameters were tabulated in Table 1 . To evaluate the wear rate, digital balance $( \pm 0.1 \mathrm{mg}$ accuracy) was used to weight specimens before and after wear. Difference between the two weights divided by the sliding distance represents the wear rate.

The friction force was measured continuously throughout the wear test using a load cell of $40 \mathrm{~kg}$. A load cell was connected to a calibrated data logger, which recorded the friction force each one millisecond, and their average values were introduced. COF was estimated by dividing the friction force by the applied normal force.

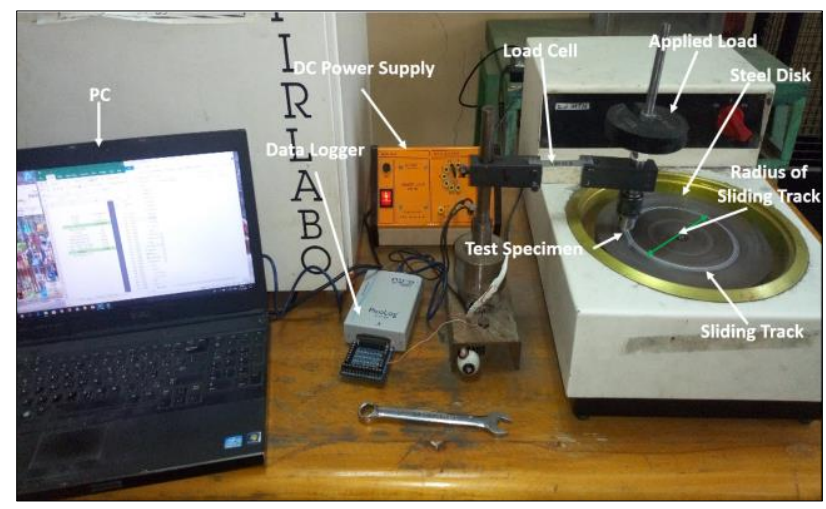

Figure 1. Pin-on-disc test rig 
Table 1. Wear test parameters

\begin{tabular}{|c|c|}
\hline Parameters (Units) & Experimental conditions \\
\hline Applied loads $(\mathrm{N})$ & $10,20,30,40$, and 50 \\
\hline Sliding speed $(\mathrm{m} / \mathrm{s})$ & 1.256 \\
\hline Temperature $\left({ }^{\circ} \mathrm{C}\right)$ & $25 \pm 2$ \\
\hline Sliding distance $(\mathrm{m})$ & 226 \\
\hline
\end{tabular}

\section{Results and discussions}

Figures $2 \mathrm{a}$ and $\mathrm{b}$ show the results of compression test conducted on the unfilled PMMA and its composites with different loadings of $\mathrm{ZrO}_{2} \mathrm{NPs}$ and $\mathrm{Al}_{2} \mathrm{O}_{3} \mathrm{NWs}$ and plotted in stress-strain curves to evaluate the elastic modulus of tested composites.
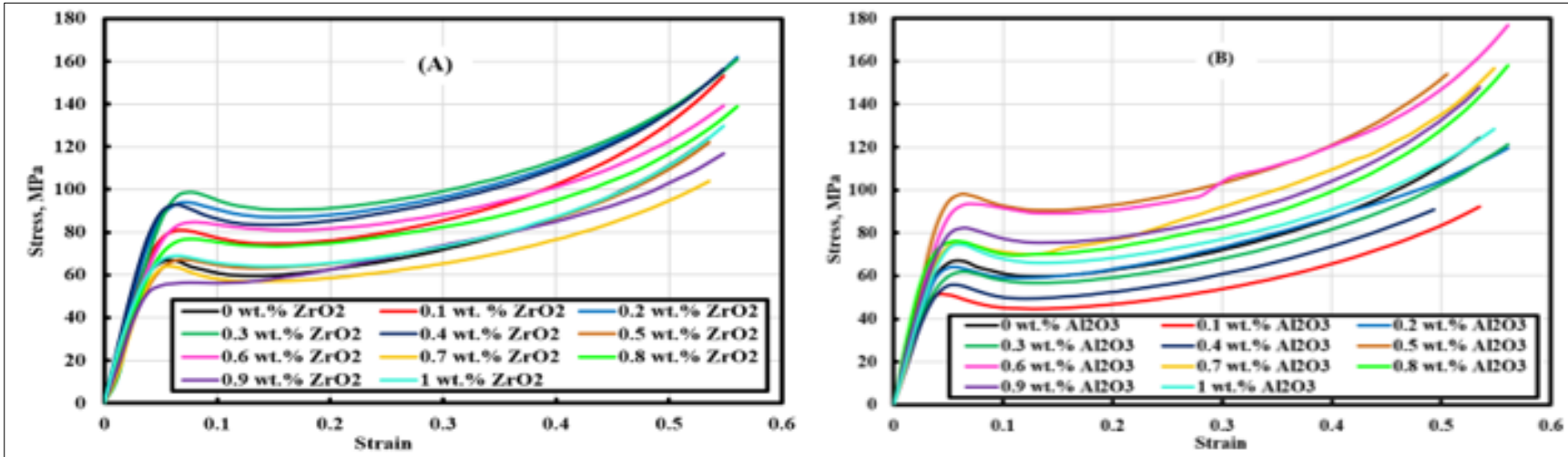

Figure 2 Engineering stress strain curves of unfilled PMMA and its nanocomposites with different loadings of: A) $\mathrm{ZrO}_{2} \mathrm{NPs}$, and B) $\mathrm{Al}_{2} \mathrm{O}_{3} \mathrm{NWs}$

Elastic modulus of PMMA nanocomposites showed gradually increasing trend after addition of $\mathrm{Al}_{2} \mathrm{O}_{3} \mathrm{NWs}$ up to $0.5 \mathrm{wt}$. \% and $\mathrm{ZrO}_{2} \mathrm{NPs}$ up to $0.7 \mathrm{wt}$. \% loading, after that it showed gradually decreasing trend with further content increase, as indicated in Figure 3. This may be due to complete saturation of the polymer matrix with $\mathrm{Al}_{2} \mathrm{O}_{3} \mathrm{NWs}$ and $\mathrm{ZrO}_{2} \mathrm{NPs}$, or may be the weak interaction between $\mathrm{Al}_{2} \mathrm{O}_{3} \mathrm{NWs}$ after 0.5 wt. $\%$ and $\mathrm{ZrO}_{2}$ NPs after 0.7 wt.\% with PMMA, that leads to less effective stress transfer between PMMA and the reinforcement materials $[22,28,40]$.

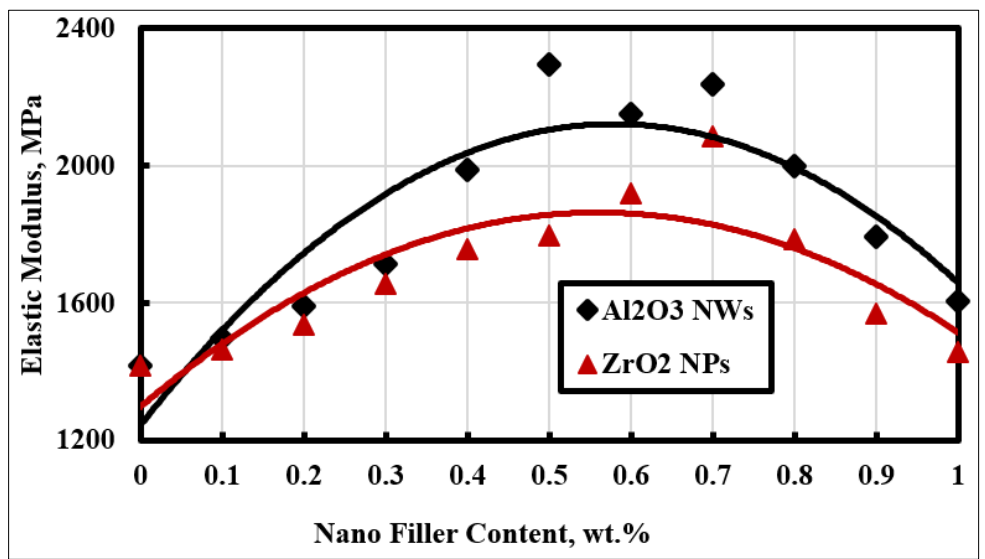

Figure 3. Elastic modulus of unfilled PMMA and its nanocomposites

According to rule of mixtures, the elastic modulus is expected to increase with increasing $\mathrm{Al}_{2} \mathrm{O}_{3} \mathrm{NWs}$ content, as observed by J. ASH et al. [31]. It is because $\mathrm{Al}_{2} \mathrm{O}_{3} \mathrm{NWs}$ and $\mathrm{ZrO}_{2} \mathrm{NPs}$ nanofillers have high elastic modulus, and the applied stress transferred from the PMMA to $\mathrm{Al}_{2} \mathrm{O}_{3} \mathrm{NWs}$ and $\mathrm{ZrO}_{2} \mathrm{NPs}$. Figure 
3 shows that $\mathrm{Al}_{2} \mathrm{O}_{3} \mathrm{NWs}$ and $\mathrm{ZrO}_{2}$ NPs increased the elastic modulus of the unfilled PMMA by 47 and $61.88 \%$ at 0.5 and 0.7 wt. \% loading, respectively.

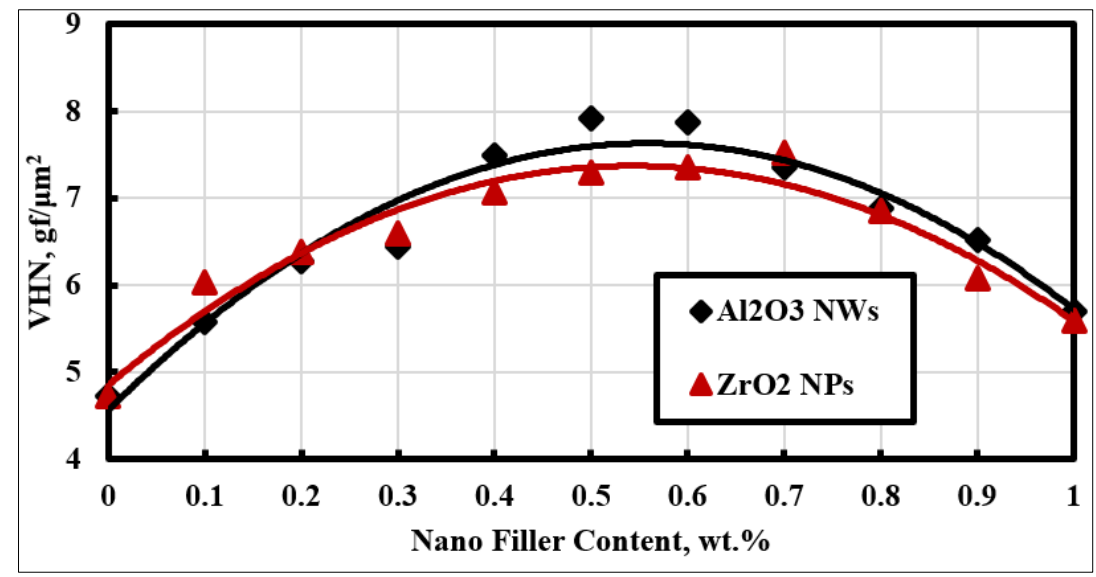

Figure 4. Microhardness of pure PMMA and its nanocomposites

Figure 4 represents the microhardness measurements of the tested $\mathrm{PMMA} / \mathrm{Al}_{2} \mathrm{O}_{3} \mathrm{NWs}$ and $\mathrm{PMMA} / \mathrm{ZrO}_{2}$ NPs composites. Microhardness test was used to predict the wear resistance of proposed dental composite material. As indicated from Figure 4, the microhardness of composites is higher than that of the unfilled PMMA. $\mathrm{Al}_{2} \mathrm{O}_{3} \mathrm{NWs}$ and $\mathrm{ZrO}_{2}$ NPs increased the microhardness of the unfilled PMMA by 67.26 and $59.08 \%$ at 0.5 and 0.7 wt. \% loadings, respectively.

The strong interfacial adhesion between the nanofillers of $\mathrm{Al}_{2} \mathrm{O}_{3} \mathrm{NWs}$ at $0.5 \mathrm{wt}$. $\%$ and $\mathrm{ZrO}_{2} \mathrm{NPs}$ at 0.7 wt. \% loadings with PMMA matrix, and the molecular-level dispersion of these nanofillers in the matrix may be the reasons of the higher microhardness of the composites. $\mathrm{Also}, \mathrm{Al}_{2} \mathrm{O}_{3} \mathrm{NWs}$ and $\mathrm{ZrO}_{2}$ NPs act as strengthening material of the polymer matrix nanocomposites that contribute to improvement in load carrying capacity. The results obtained agree with Asopa et al. [28].

Experimental results of wear test for the examined PMMA/Al $\mathrm{O}_{3} \mathrm{NWs}$, and $\mathrm{PMMA} / \mathrm{ZrO}_{2} \mathrm{NPs}$ composites at constant sliding distance and different applied loads of 10, 20, 30, 40, and $50 \mathrm{~N}$ were introduced in Figures 5 and 6, respectively.

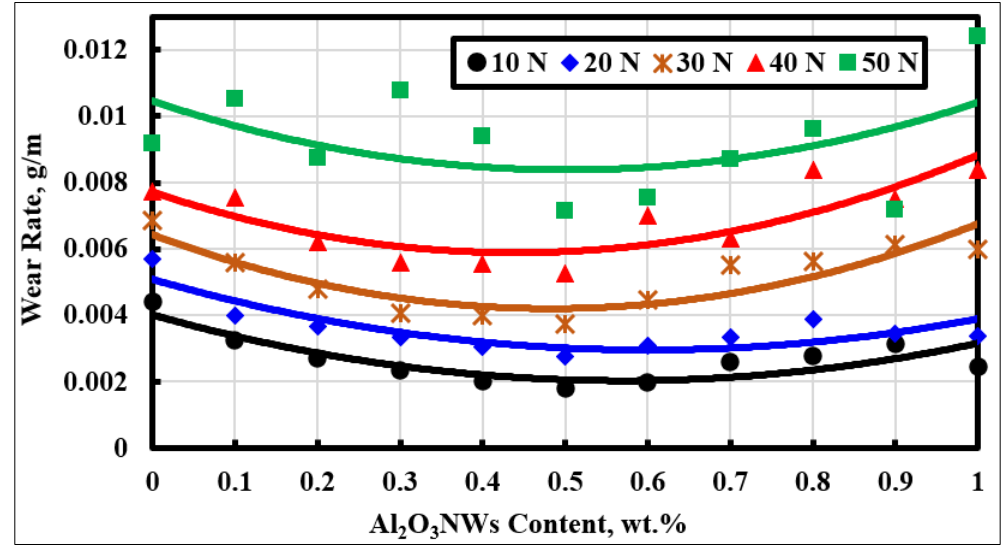

Figure 5. Wear rate of $\mathrm{PMMA} / \mathrm{Al}_{2} \mathrm{O}_{3} \mathrm{NWs}$ composites at different applied loads 


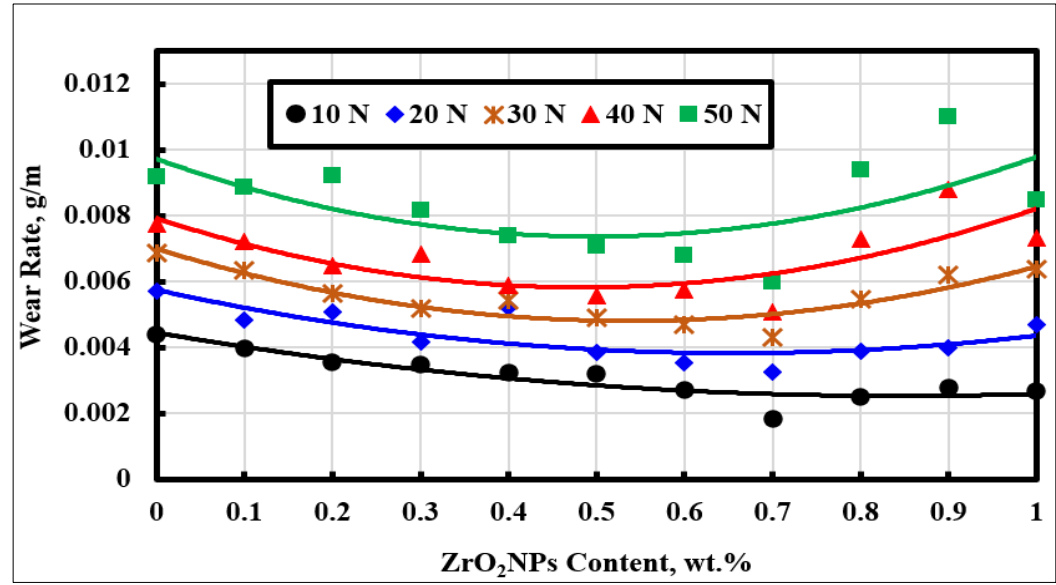

Figure 6. Wear rate of PMMA/ZrO $\mathrm{PH}_{2}$ NPs composites at different applied loads

As indicated in these Figures, addition of $\mathrm{Al}_{2} \mathrm{O}_{3} \mathrm{NWs}$ up to 0.5 wt. $\%$ and $\mathrm{ZrO}_{2}$ NPs up to 0.7 wt. $\%$ can significantly improve the wear rate of unfilled PMMA by 59.09, 51.75, 45.36, 31.91, and $21.81 \%$ for $\mathrm{Al}_{2} \mathrm{O}_{3} \mathrm{NWs}$ and 58.33, 42.69, 37.34, 34.34, and $34.58 \%$ for $\mathrm{ZrO}_{2} \mathrm{NPs}$ under applied loads of 10, 20, 30,40 , and $50 \mathrm{~N}$, respectively. This may be attributed to the well dispersion of $\mathrm{ZrO}_{2} \mathrm{NPs}$ and $\mathrm{Al}_{2} \mathrm{O}_{3}$ NWs in PMMA matrix material that led to enhancing the wear resistance by protection of PMMA matrix from abrasion, as shown in morphological analysis by SEM images in Figures $10 \mathrm{~b}$ and $\mathrm{d}$.

Also, it is evident from Figures 5 and 6 that an increasing trend in wear rate was shown at $0.5 \mathrm{wt} \%$ and above of $\mathrm{Al}_{2} \mathrm{O}_{3} \mathrm{NWs}$ and 0.7 of $\mathrm{ZrO}_{2} \mathrm{NPs}$ at different applied loads. This may be due to nonuniform distribution and agglomeration of $\mathrm{Al}_{2} \mathrm{O}_{3} \mathrm{NWs}$ and $\mathrm{ZrO}_{2}$ NPs nanofillers inside the matrix material of PMMA that lead to porosity formation, as shown in SEM images in Figure $10 \mathrm{c}$ and e. It should be noticed that the homogenous distribution of the nanofillers in PMMA matrix material is one of the most important factor for determining wear performance of the composite [41]. On the other hand, there is relationship between the hardness number and wear resistance of the composite as explained by Archard equation. Therefore, the hardness plays an important role to improve the wear resistance of the composite according to Archard equation [42]. As indicated in Figure 4, microhardness of the composites increases with increase of nanofillers content of $\mathrm{Al}_{2} \mathrm{O}_{3} \mathrm{NWs}$ and $\mathrm{ZrO}_{2} \mathrm{NPs}$ up to 0.5 and $0.7 \mathrm{wt}$. \%, respectively. For this reason, wear resistance was enhanced due to an enhancement that occurred in the hardness of the composites.

In the meantime, wear rate values of the present nanocomposites of $\mathrm{PMMA} / \mathrm{Al}_{2} \mathrm{O}_{3} \mathrm{NWs}$ and $\mathrm{PMMA} / \mathrm{ZrO}_{2}$ NPs showed increasing trend by increasing the applied loads up to $50 \mathrm{~N}$. This may be due to penetration of the sliding disk asperities to the softer specimen contact surface, where the asperities of the softer surface were abraded. Also, the increase in the applied load during the wear test led to increasing the surface area of the tested specimen at the contact zone with the sliding disk, (Figure 7), that increased the resulting wear rate values [43-45].
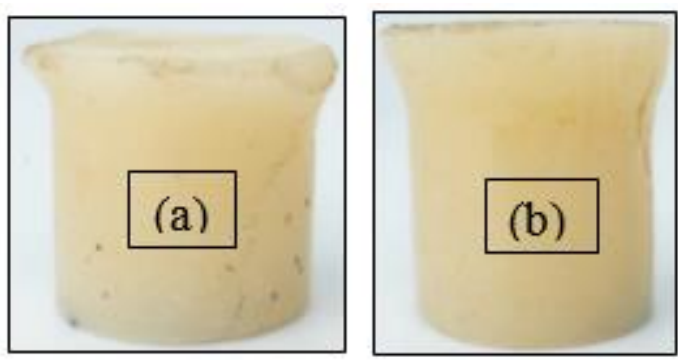

Figure 7. Specimens after wear test under applied load of $50 \mathrm{~N}$ :

a) $\mathrm{PMMA} / 0.5 \mathrm{Al}_{2} \mathrm{O}_{3} \mathrm{NWs}$, and

b) PMMA/0.7 $\mathrm{ZrO}_{2} \mathrm{NPs}$

Depending on the variations of COF versus $\mathrm{Al}_{2} \mathrm{O}_{3} \mathrm{NWs}$ and $\mathrm{ZrO}_{2} \mathrm{NPs}$ as nanofillers content at different applied loads up to $50 \mathrm{~N}$, COF of unfilled PMMA showed significant enhancement by 
increasing $\mathrm{Al}_{2} \mathrm{O}_{3} \mathrm{NWs}$ up to 0.5 wt. $\%$ and $\mathrm{ZrO}_{2} \mathrm{NPs}$ up to 0.7 wt. \%. After addition of $\mathrm{Al}_{2} \mathrm{O}_{3} \mathrm{NWs}$ and $\mathrm{ZrO}_{2}$, NPs nanofillers more than 0.5 and $0.7 \mathrm{wt}$ \%, respectively, COF showed gradual increasing trend. This may be attributed to poor interaction between PMMA matrix material and the nanofillers at higher contents, that led to agglomeration and porosity in the specimen, as shown in Figure $10 \mathrm{c}$ and e. $\mathrm{Al}_{2} \mathrm{O}_{3}$ NWs at 0.5 wt. \% reduced the COF of unfilled PMMA by $24.28,17.48,18.93,30.81$, and $25.47 \%$ under applied loads of 10, 20, 30, 40, and $50 \mathrm{~N}$, respectively, as given in Figure 8. Also, $\mathrm{ZrO}_{2} \mathrm{NPs}$ at 0.7 wt. $\%$ enhanced the COF of unfilled PMMA by 23.67, 26.68, 33.03, 38.46, and $40.87 \%$ under applied loads of 10, 20, 30, 40, and $50 \mathrm{~N}$, respectively, as shown in Figure 9.

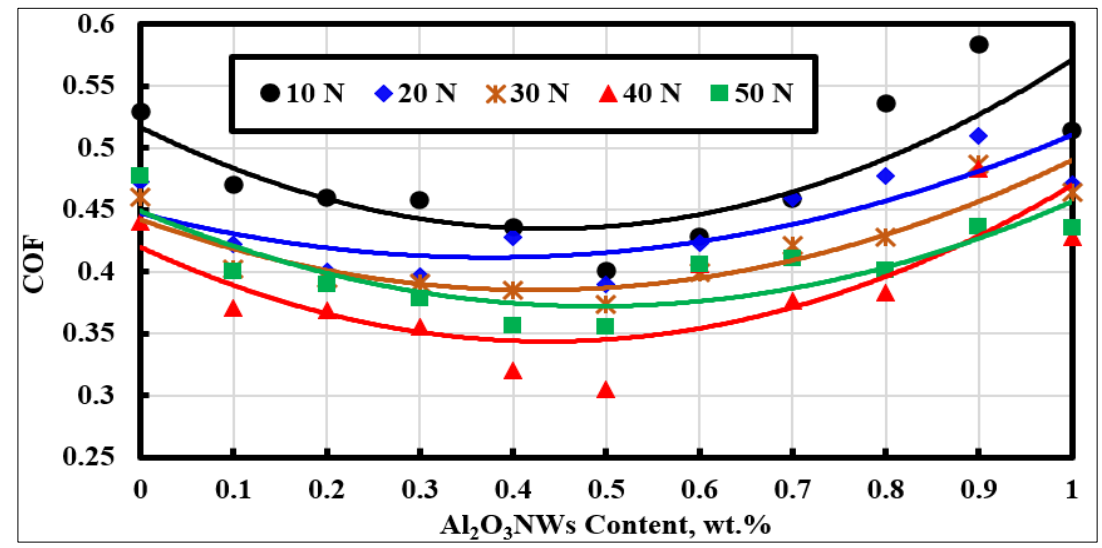

Figure 8. COF of $\mathrm{PMMA} / \mathrm{Al}_{2} \mathrm{O}_{3} \mathrm{NWs}$ composites at different applied loads

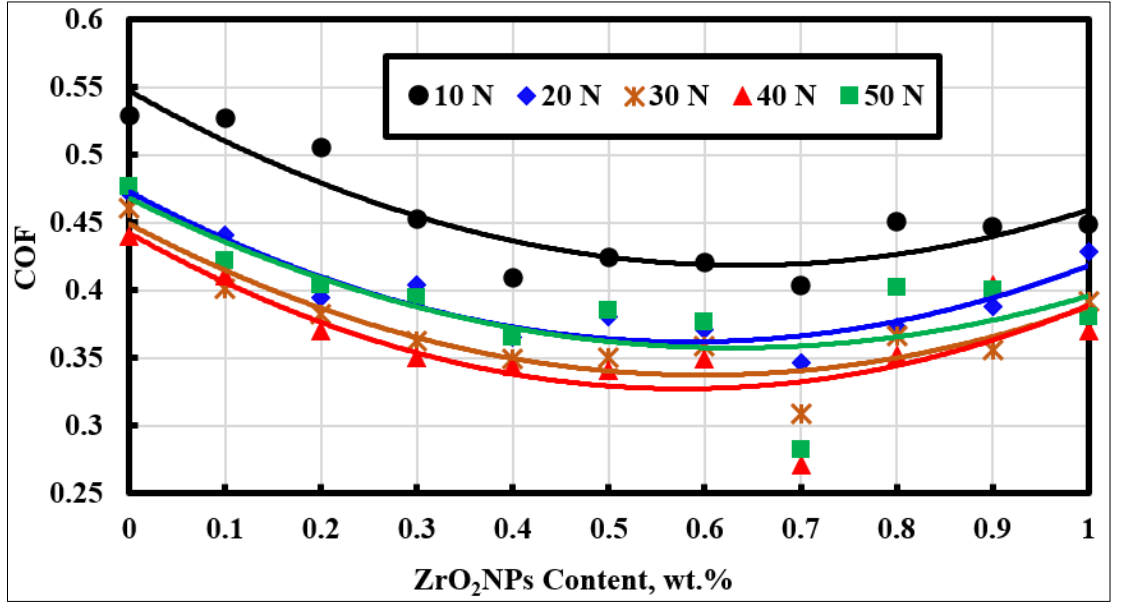

Figure 9. COF of PMMA/ZrO $\mathrm{ZP}_{2}$ NPs composites at different applied loads

As introduced in Figures 8 and 9, COF was improved by increasing applied load up to 40 N. This may be due to the generated temperature between sliding disk and contact zone of the specimens that decreases shear strength of PMMA matrix material [46, 47]. Therefore, the lowest COF values of PMMA reinforced with $\mathrm{Al}_{2} \mathrm{O}_{3} \mathrm{NWs}$ at 0.5 wt. $\%$ and $\mathrm{ZrO}_{2} \mathrm{NPs}$ at 0.7 wt. \% were recorded under applied load of $40 \mathrm{~N}$, whereas when the applied load was increased up to $50 \mathrm{~N}$, COF of the composites showed increasing trend because of increasing surface area of the wear test specimen at the contact zone with the sliding disk led to increasing the resulting COF value, as mentioned previously in Figure 7.

Examination of worn surfaces after wear test of unfilled PMMA, PMMA/0.5 wt. $\% \mathrm{Al}_{2} \mathrm{O}_{3} \mathrm{NWs}$, PMMA/1 wt. \% $\mathrm{Al}_{2} \mathrm{O}_{3}$ NWs, PMMA/0.7 wt. \% $\mathrm{ZrO}_{2}$ NPs, and PMMA/1 wt. \% $\mathrm{ZrO}_{2} \mathrm{NPs}$ under applied load of $50 \mathrm{~N}$ were investigated by SEM are introduced in Figure 10. As seen in Figure 10 a, the worn surface of unfilled PMMA contains many deep grooves and ploughed marks. This corresponds to the wear rate and COF results of unfilled PMMA, and it also illustrates that the adhesive wear mechanism was occurred. On the whole, more adhesive wear was occurred mainly because of the softening of 
unfilled PMMA caused by generated temperature between sliding disk and specimen at a contact zone. Moreover, counterface asperities penetration into the soft unfilled PMMA are responsible for the occurrence of surface microploughing.
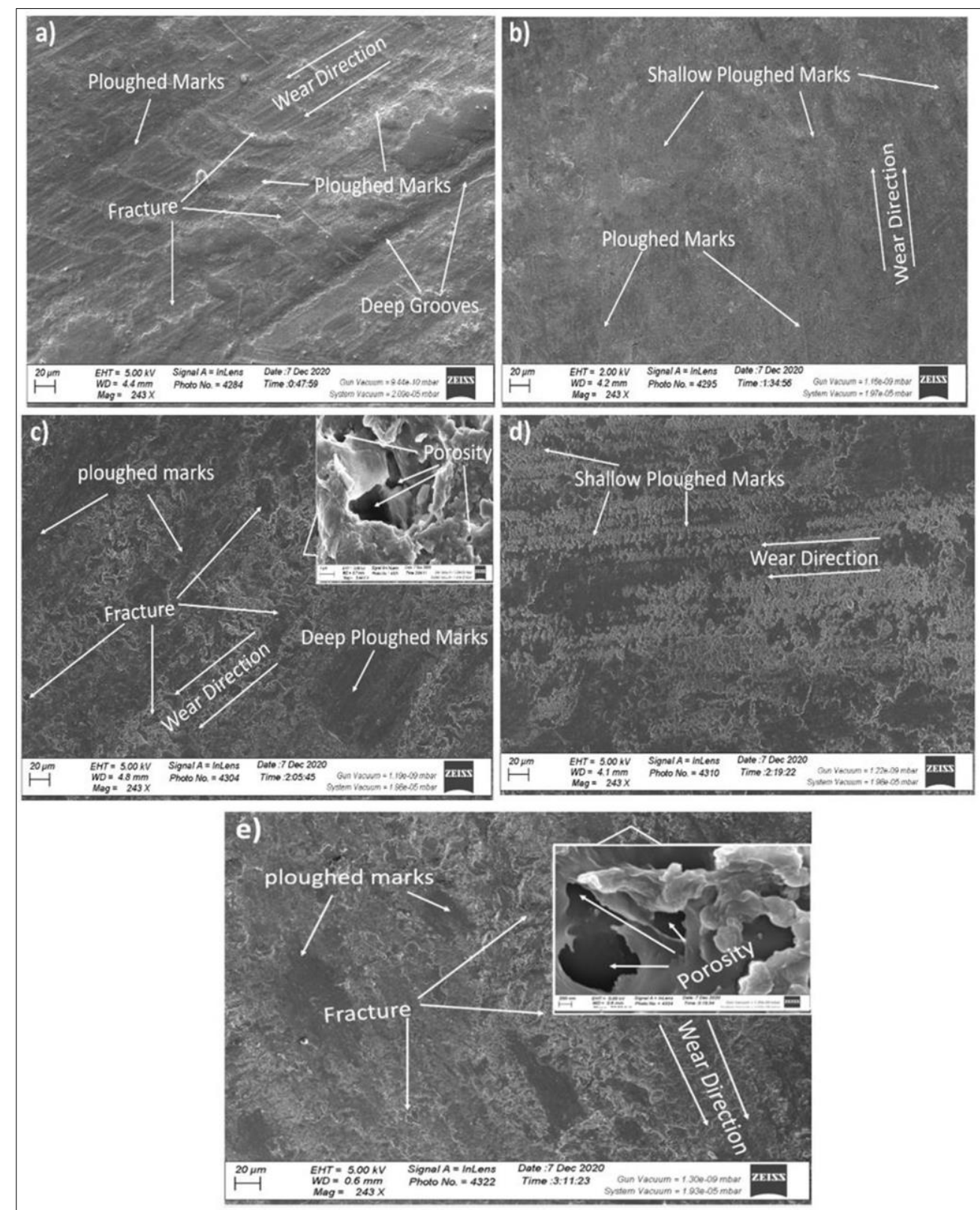

After adding of 0.5 wt. $\% \mathrm{Al}_{2} \mathrm{O}_{3} \mathrm{NWs}$ and $\mathrm{ZrO}_{2} \mathrm{NPs} 0.7$ wt. \% into PMMA, mechanical strength of the surface of the specimens was enhanced and showed dramatically decreased wear grooves, as indicated in Figure $10 \mathrm{~b}$ and d, respectively. Moreover, during sliding wear process, the formed transfer film also plays an effective role in improving the surface wear characteristics [48].

Nanofillers of $\mathrm{Al}_{2} \mathrm{O}_{3}$ NWs and $\mathrm{ZrO}_{2}$ NPs were dragged out from PMMA during sliding wear then transferred to the contact zone of PMMA nanocomposites and sliding disk surface, that was contributed in enhancement of the specimens worn surfaces, as seen in Figure $10 \mathrm{~b}$ and d. Consequently, the best improvement of wear rate and COF of PMMA nanocomposites were achieved after adding of $\mathrm{Al}_{2} \mathrm{O}_{3}$ NWs up to 0.5 wt. $\%$ and $\mathrm{ZrO}_{2} \mathrm{NPs}$ up to $0.7 \mathrm{wt}$. \%. This may be attributed to releasing of $\mathrm{Al}_{2} \mathrm{O}_{3} \mathrm{NWs}$ and $\mathrm{ZrO}_{2}$ NPs from PMMA nanocomposites between the contacted surfaces, which act as a lubricant material between them.

After adding of $\mathrm{Al}_{2} \mathrm{O}_{3} \mathrm{NWs}$ and $\mathrm{ZrO}_{2}$ NPs to PMMA more than $0.5 \mathrm{wt} . \%$ and $0.7 \mathrm{wt} . \%$, respectively up to $1 \mathrm{wt} . \%$, as shown in Figure $10 \mathrm{c}$ and e, there were more ploughed marks and porosity formation 
on worn surfaces than those of PMMA at 0.5 wt. $\% \mathrm{Al}_{2} \mathrm{O}_{3} \mathrm{NWs}$ and 0.7 wt. $\% \mathrm{ZrO}_{2} \mathrm{NPs}$. This may be because of nanofillers agglomeration and porous formation that occur due to poor interaction between nanofillers at large contents and PMMA matrix material. For this reason, wear rate and COF properties were decreased, also surface characteristics were deteriorated with increasing of $\mathrm{Al}_{2} \mathrm{O}_{3} \mathrm{NWs}$ and $\mathrm{ZrO}_{2}$ NPs more than $0.5 \mathrm{wt} . \%$ and $0.7 \mathrm{wt} . \%$, respectively up to $1 \mathrm{wt} . \%$.

\section{Conclusions}

In the present study, PMMA matrix material reinforced with two nanofillers of $\mathrm{Al}_{2} \mathrm{O}_{3} \mathrm{NWs}$ and $\mathrm{ZrO}_{2}$ NPs were fabricated, where the mechanical and tribological performance of the present nanocomposites were investigated for denture materials applications. Mechanical properties including elastic modulus and microhardness, and tribological properties including wear rate and COF under applied loads up to $50 \mathrm{~N}$ of unfilled PMMA matrix material were enhanced with increasing $\mathrm{Al}_{2} \mathrm{O}_{3} \mathrm{NWs}$ and $\mathrm{ZrO}_{2} \mathrm{NPs}_{\text {up }}$ to 0.5 and $0.7 \mathrm{wt} \%$, respectively. This may be attributed to the high mechanical properties of these nanofillers, as well as the matrix material of PMMA was able to be strengthened after adding these nanofillers. In the meantime, worn surfaces were enhanced due to the nanofillers of $\mathrm{Al}_{2} \mathrm{O}_{3} \mathrm{NWs}_{\mathrm{s}}$ and $\mathrm{ZrO}_{2}$ NPs were dragged out from PMMA during sliding wear then transferred to the contact zone of PMMA nanocomposites and sliding disk surface, leading to the enhancement of the specimens worn surfaces.

PMMA nanocomposites that contain nanofillers loading more than 0.5 wt. $\% \mathrm{Al}_{2} \mathrm{O}_{3} \mathrm{NWs}$ and 0.7 wt. $\% \mathrm{ZrO}_{2}$ NPs recorded lower elastic modulus and microhardness, and higher wear rate and COF properties than that of at 0.5 and $0.7 \mathrm{wt}$. \% under applied loads up to $50 \mathrm{~N}$. This may be because of agglomeration and porosity formation, which led to weak interaction between the matrix material of PMMA and nanofillers of $\mathrm{Al}_{2} \mathrm{O}_{3} \mathrm{NWs}$ and $\mathrm{ZrO}_{2} \mathrm{NPs}$. Wear rate was increased with increase in applied loads up to $50 \mathrm{~N}$, whereas COF showed decreased trend with increasing applied loads up to $40 \mathrm{~N}$. Also, worn surfaces showed contain more ploughed marks and porosity formation than those of PMMA at 0.5 wt. $\% \mathrm{Al}_{2} \mathrm{O}_{3} \mathrm{NWs}$ and $0.7 \mathrm{wt} . \% \mathrm{ZrO}_{2} \mathrm{NPs}$. This may be because of nanofillers agglomeration and porous formation that occur due to poor interaction between nanofillers at large contents and PMMA matrix material.

Acknowledgements: This work was supported by materials lab in production technology Dept. - faculty of technology and education, Beni-Suef University, Beni-Suef, Egypt.

\section{References}

1.G. VENUGOPAL, J. C. VEETIL, N. RAGHAVAN, V. SINGH, A. KUMAR, A. MUKKANNAN., Nano-dynamic mechanical and thermal responses of single-walled carbon nanotubes reinforced polymer nanocomposite thinfilms, J. Alloys Compd., 688, 2016, 454-459, doi: 10.1016/j.jallcom.2016.07.209.

2.S. K. PEDDINI, C. P. BOSNYAK, N. M. HENDERSON, C. J. ELLISON, D. R. PAUL., Nanocomposites from styrene-butadiene rubber (SBR) and multiwall carbon nanotubes (MWCNT) part 1: Morphology and rheology, Polymer (Guildf)., 55(1), 2014, 258-270,

doi: 10.1016/j.polymer.2013.11.003.

3. B. ALI SABRI, M. SATGUNAM, N. M. ABREEZA, A. N. ABED., A review on enhancements of PMMA Denture Base Material with Different Nano-Fillers, Cogent Eng., 8(1), 2021, doi: 10.1080/23311916.2021.1875968.

4. M. M. GAD, A. M. AL-THOBITY, A. RAHOMA, R. ABUALSAUD, F. A. AL-HARBI, S. AKHTAR., Reinforcement of PMMA denture base material with a mixture of $\mathrm{ZrO}_{2}$ nanoparticles and glass fibers, Int. J. Dent., 2019, 2019, doi: 10.1155/2019/2489393.

5. N. HERRERA, A. P. MATHEW, K. OKSMAN., Plasticized polylactic acid/cellulose nanocomposites prepared using melt-extrusion and liquid feeding: Mechanical, thermal and optical properties, Compos. Sci. Technol., 106, 2015, 149-155, doi: 10.1016/j.compscitech.2014.11.012. 
6. R. BALEN ET AL., Structural, thermal, optical properties and cytotoxicity of PMMA/ZnO fibers and films: Potential application in tissue engineering, Appl. Surf. Sci., 385, 2016, 257-267, doi: 10.1016/j.apsusc.2016.05.122.

7. M. ALAMGIR, A. MALLICK, G. C. NAYAK, S. K. TIWARI., Development of PMMA/TiO 2 nanocomposites as excellent dental materials, J. Mech. Sci. Technol., 33(10), 2019, 4755-4760, doi: 10.1007/s12206-019-0916-7.

8. A. O. ALHAREB, Z. A. AHMAD., Effect of $\mathrm{Al}_{2} \mathrm{O}_{3} / \mathrm{ZrO}_{2}$ reinforcement on the mechanical properties of PMMA denture base, J. Reinf. Plast. Compos., 30(1), 2011, 86-93, doi: 10.1177/0731684410379511. 9. A. O. ALHAREB, H. M. AKIL, Z. A. AHMAD., Mechanical Properties of PMMA Denture Base Reinforced by Nitrile Rubber Particles with $\mathrm{Al}_{2} \mathrm{O}_{3} /$ YSZ Fillers, Procedia Manuf., 2(February), 2015, 301-306, doi: 10.1016/j.promfg.2015.07.053.

10. A. AKINCI, S. SEN, U. SEN., Friction and wear behavior of zirconium oxide reinforced PMMA composites, Compos. Part B Eng., 56, 2014, 42-47, doi: 10.1016/j.compositesb.2013.08.015.

11. N. MURAKAMI, N. WAKABAYASHI, R. MATSUSHIMA, A. KISHIDA, Y. IGARASHI., Effect of high-pressure polymerization on mechanical properties of PMMA denture base resin, J. Mech. Behav. Biomed. Mater., 20, 2013, 98-104, doi: 10.1016/j.jmbbm.2012.12.011.

12. G. E. CARLSSON, R. OMAR., The future of complete dentures in oral rehabilitation. A critical review, J. Oral Rehabil., 37(2), 2010, 143-156, doi: 10.1111/j.1365-2842.2009.02039.x.

13. P. YADAV, R. MITTAL, V. K. SOOD, R. GARG., Effect of Incorporation of Silane-Treated Silver and Aluminum Microparticles on Strength and Thermal Conductivity of PMMA, J. Prosthodont., 21(7), 2012, 546-551, doi: 10.1111/j.1532-849X.2012.00873.x.

14. R. ADHIKARI, G. H. MICHLER., Polymer nanocomposites characterization by microscopy, Polym. Rev., 49(3), 2009, 141-180, doi: 10.1080/15583720903048094.

15. P. CHAIJAREENONT, H. TAKAHASHI, N. NISHIYAMA, M. ARKSORNNUKIT., Effect of different amounts of 3-methacryloxypropyltrimethoxysilane on the flexural properties and wear resistance of alumina reinforced PMMA, Dent. Mater. J., 31(4), 2012, 623-628,

doi: $10.4012 /$ dmj.2012-056.

16. L. M. A. MENG T. R., Physical properties of four acrylic denture base resins, J Contemp Dent Pr. 2005;693-100., 6( 4), 2005, 1-5.

17. R. KRISHNA ALLA ET AL., Conventional and Contemporary polymers for the fabrication of denture prosthesis: part I-Overview, composition and properties, $\sim 82 \sim$ Int. J. Appl. Dent. Sci., 1(4), 2015, 82-89.

18.R. ROY., Purposive design of nanocomposites: entire class of new materials, Mater. Sci. Res., 21, 1987, 25-32, doi: https://doi.org/10.1007/978-1-4613-1933-7_3.

19.M. Z. RONG, M. Q. ZHANG, Y. X. ZHENG, H. M. ZENG, R. WALTER, K. FRIEDRICH., Structure-property relationships of irradiation grafted nano-inorganic particle filled polypropylene composites, Polymer (Guildf)., 421, 2001, 167-183, 2001, doi: 10.1016/S0032-3861(00)00325-6.

20.F. ASHENAI GHASEMI, S. DANESHPAYEH, I. GHASEMI, M. AYAZ., An investigation on the Young's modulus and impact strength of nanocomposites based on polypropylene/linear low-density polyethylene/titan dioxide (PP/LLDPE/TiO 2 ) using response surface methodology, Polym. Bull., 73(6), 2016, 1741-1760, doi: 10.1007/s00289-015-1574-2.

21.S. SRIVASTAVA, R. K. TIWARI., Synthesis of epoxy-TiO 2 nanocomposites: A study on sliding wear behavior, thermal and mechanical properties, Int. J. Polym. Mater. Polym. Biomater., 61(13), 2012, 999-1010, doi: 10.1080/00914037.2011.617326.

22.M. M. GAD, S. M. FOUDA, F. A. AL-HARBI, R. NÄPÄNKANGAS, A. RAUSTIA., PMMA denture base material enhancement: A review of fiber, filler, and nanofiller addition, Int. J. Nanomedicine, 12, 2017, 3801-3812, doi: 10.2147/IJN.S130722.

23.R. MEDINA, F. HAUPERT, A. K. SCHLARB., Improvement of tensile properties and toughness of an epoxy resin by nanozirconium-dioxide reinforcement, J. Mater. Sci., 43(9), 2008, 3245-3252, doi: 10.1007/s10853-008-2547-8. 
24.M. M. GAD, A. RAHOMA, A. M. AL-THOBITY, A. S. ARREJAIE., Influence of incorporation of $\mathrm{ZrO}_{2}$ nanoparticles on the repair strength of polymethyl methacrylate denture bases, Int. J. Nanomedicine, 11, 2016, 5633-5643, doi: 10.2147/IJN.S120054.

25.N. V. ASAR, H. ALBAYRAK, T. KORKMAZ, I. TURKYILMAZ., Influence of various metal oxides on mechanical and physical properties of heat-cured polymethyl methacrylate denture base resins, J. Adv. Prosthodont., 5(3), 2013, 241-247, doi: 10.4047/jap.2013.5.3.241.

26.P. FRANKLIN, D. J. WOOD, N. L. BUBB., Reinforcement of poly(methyl methacrylate) denture base with glass flake, Dent. Mater., 21(4), 2005, 365-370, doi: 10.1016/j.dental.2004.07.002.

27.A. E. ELLAKWA, M. A. MORSY, A. M. EL-SHEIKH., Effect of aluminum oxide addition on the flexural strength and thermal diffusivity of heat-polymerized acrylic resin, J. Prosthodont., 17(6), 2008, 439-444, doi: 10.1111/j.1532-849X.2008.00318.x.

28.V. ASOPA, S. SURESH, M. KHANDELWAL, V. SHARMA, S. S. ASOPA, L. S. KAIRA., A comparative evaluation of properties of zirconia reinforced high impact acrylic resin with that of high impact acrylic resin, Saudi J. Dent. Res., 6(2), 2015, 146-151, doi: 10.1016/j.sjdr.2015.02.003.

29.E. KUL, L. İ. ALADAĞ, R. YESILDAL., Evaluation of thermal conductivity and flexural strength properties of poly(methyl methacrylate) denture base material reinforced with different fillers, $J$. Prosthet. Dent., 116(5), 2016, 803-810, doi: 10.1016/j.prosdent.2016.03.006.

30.A. NAVIDFAR, T. AZDAST, A. KARIMZAD GHAVIDEL., Influence of processing condition and carbon nanotube on mechanical properties of injection molded multi-walled carbon nanotube/poly (methyl methacrylate) nanocomposites, J. Appl. Polym. Sci., 133(31), 2016, 1-10,

doi: 10.1002/app.43738.

31.B. J. ASH ET AL., Mechanical properties of Al2O3/polymethylmethacrylate nanocomposites, Polym. Compos., 23(6), 2002, 1014-1025, doi: 10.1002/pc.10497.

32.A. AL-KAWAZ ET AL., Tribological and mechanical investigation of acrylic-based nanocomposite coatings reinforced with PMMA-grafted-MWCNT, Mater. Chem. Phys., 175, 2016, 206-214, doi: 10.1016/j.matchemphys.2016.03.021.

33.H. LIU, H. YE, T. LIN, T. ZHOU., Synthesis and characterization of $\mathrm{PMMA} \mathrm{Al}_{2} \mathrm{O}_{3}$ composite particles by in situ emulsion polymerization, Particuology, 6(3), 2008, 207-213,

doi: 10.1016/j.partic.2008.01.003.

34.N. A. BEZY, A. L. FATHIMA., Effect of $\mathrm{TiO}_{2}$ nanoparticles on Mechanical Properties of EpoxyResin System, Int. J. Eng. Res. Gen. Sci. Vol., 3(5), 2015, 143-151.

35.A. A. BERRIN AKKUS, A NILGUN OZTURK, SAKIR YAZMAN., Effects of $\mathrm{Al}_{2} \mathrm{O}_{3}$ and $\mathrm{SiO}_{2}$ nanoparticles on flexural strength of heat cure acrylic resin, Int. J. Enhanc. Res. Sci. Technol. Eng., 4(6), 2015, 158-163,.

36.B. S. JASIM, I. J. ISMAIL., The Effect of Silanized Alumina Nano - Fillers Addition on Some Physical and Mechanical Properties of Heat Cured Polymethyl Methacrylate Denture Base Material, $J$. Baghdad Coll. Dent., 26(2), 2014, 18-23, doi: 10.12816/0015190.

37.A. A. N, M. A. M., Evaluation of thermal conductivity of alumina reinforced heat cure acrylic resin and some other properties, J Bagh Coll. Dent., 22(3), 2010 1-7.

38.V. JAIN, N. ARORA, A. CHAWLA, V. P. MATHUR., Effect of Addition of Sapphire (Aluminium Oxide) or Silver Fillers on the Flexural Strength Thermal Diffusivity and Water Sorption of Heat Polymerized Acrylic Resins, Int. J. Prosthodont. Restor. Dent., 1(1), 2011, 21-27,

doi: 10.5005/jp-journals-10019-1004.

39.A. F. WADY, A. L. MACHADO, V. ZUCOLOTTO, C. A. ZAMPERINI, E. BERNI, C. E. VERGANI., Evaluation of Candida albicans adhesion and biofilm formation on a denture base acrylic resin containing silver nanoparticles, J. Appl. Microbiol., 112(6), 2012, 1163-1172,

doi: 10.1111/j.1365-2672.2012.05293.x.

40.M. AHMED, M. EBRAHIM., Effect of Zirconium Oxide Nano-Fillers Addition on Mechanical Properties of Heat-Polymerized Acrylic Resin, Al-Azhar Dent. J. Girls, 3(1), 2016, 41-48, doi: 10.21608/adjg.2016.5068. 
41.H. J. PARK, S. Y. KWAK, S. KWAK., Wear-resistant ultra high molecular weight polyethylene/ zirconia composites prepared by in situ ziegler-natta polymerization, Macromol. Chem. Phys., 206(9), 2005, 945-950, doi: 10.1002/macp.200400350.

42.E. HORNBOGEN., Role of Fracture Toughness in the Wear of Metals., Wear., 33(2), 1975, 251259.

43.A. E. M. HASSAN, A. I. EID, M. EL-SHEIKH, W. Y. ALI., Mechanical and tribological performance of polyamide 12 reinforced with graphene nanoplatelets and paraffin oil nanocomposites, Materwiss. Werksttech., 50(1), 2019, 74-85, doi: 10.1002/mawe.201700177.

44.B. SURESHA, K. N. S. KUMAR., Investigations on mechanical and two-body abrasive wear behaviour of glass/carbon fabric reinforced vinyl ester composites, Mater. Des., 30(6), 2009, 20562060, doi: 10.1016/j.matdes.2008.08.038.

45.B. N. RAVI KUMAR, B. SURESHA, M. VENKATARAMAREDDY., Effect of particulate fillers on mechanical and abrasive wear behaviour of polyamide 66/polypropylene nanocomposites, Mater. Des., 30(9), 2009, 3852-3858, doi: 10.1016/j.matdes.2009.01.034.

46.A. W. Y. YOUSRA A. AHMED, NOURELHODA M. MAHMOUD, EL-WAKAD M. T., Friction and wear of polymethyl methacrylate reinforced by silica and zirconia nanoparticles as dental materials, Egypt. Soc. Tribol., 15(4), 2018, 14-25.

47.W. LI, S. ZHENG, B. CAO, S. MA., Friction and wear properties of $\mathrm{ZrO}_{2} / \mathrm{SiO}_{2}$ composite nanoparticles," J. Nanoparticle Res., 13(5), 2011, 2129-2137, doi: 10.1007/s11051-010-9970-x.

48.A. E. S. M. HASSAN, A. I. EI, M. EL-SHEIKH, W. Y. ALI., Effect of Graphene Nanoplatelets and Paraffin Oil Addition on the Mechanical and Tribological Properties of Low-Density Polyethylene Nanocomposites, Arab. J. Sci. Eng., 43(3), 2018, 1435-1443, doi: 10.1007/s13369-017-2965-5.

$\overline{\text { Manuscript received: 7.04.2021 }}$ 